\title{
Analisis Penilaian Risiko Kesehatan Lingkungan dengan Menggunakan Pendekatan Environmental Health Risk Assessment (EHRA) di Kecamatan Moyo Utara
}

\author{
Iga Maliga $^{1}$, Darmin $^{2}$ \\ ${ }^{1,2}$ STIKes Griya Husada Sumbawa \\ Surel: maliga07stikesghs@gmail.com
}

\section{ABSTRAK}

Kesehatan lingkungan berperan penting dalam keseimbangan ekologi mencakup alam dan lingkungan, termasuk manusia sebagai komponen utama. Esensi dasar dalam kesehatan lingkungan adalah meningkatkan derajat kesehatan manusia. Seiring meningkatnya pola konsumsi dan jumlah penduduk, permasalahan sanitasi dan kesehatan lingkungan menjadi hal utama penunjang kesehatan masyarakat. Sanitasi dan kesehatan lingkungan sering terabaikan sehingga sangat mempengaruhi derajat kesehatan lingkungan dan menimbulkan risiko. Penelitian ini bertujuan mengetahui sejauh mana akses kesehatan lingkungan mencakup sanitasi dasar dan perilaku hidup sehat mampu menimbulkan risiko terjadinya gangguan terhadap pola kesehatan masyarakat. Penelitian ini menggunakan pendekatan kualitatif dan kuantitatif. Metode yang digunakan adalah random sampling dengan responden 240 Kepala Keluarga pada 6 desa, unit sampling yang diwawancarai adalah ibu rumah tangga. Pada aspek kualitatif, digunakan metode depth interview pada key informan untuk mengetahui faktor yang menyebabkan tingginya indeks risiko sanitasi pada kecamatan tersebut. Kecamatan Moyo Utara di Kabupaten Sumbawa merupakan salah satu wilayah yang akses terhadap sanitasi total berbasis masyarakat masih jauh dari kata layak. Hasil penelitian yang menujukkan bahwa wilayah Kecamatan Moyo Utara memiliki Indeks Risiko Sanitasi pada angka 3 dan 4, yang artinya kondisi sanitasi berada ada kategori risiko tingggi dan sangat tinggi. Desa yang dibagi pada Klaster $0-4$ memiliki tingkat sanitasi dasar yang masih rendah, terutama pada aspek air limbah, sampah dan perilaku perilaku hidup bersih dan sehat (PHBS). Hasil penelitian menunjukkan setiap strata wilayah permasalahan air limbah domestik, persampahan dan PHBS menjadi permasalahan utama yang memiliki tingkat risiko sanitasi yang cukup besar dibandingkan yang lain.
\end{abstract}

\section{Kata kunci}

Kesehatan

Lingkungan,

EHRA,

Sanitasi

\section{PENDAHULUAN}

Urgensi penyediaan akses sanitasi yang layak khususnya bagi masyarakat pedesaan baik di Indonesia maupun di negara lainnya kian mendesak. Hal inilah yang memicu PBB menetapkan sanitasi sebagai hak azazi manusia pada tahun 2010 silam $^{[1]}$. Saat ini Indonesia masih menghadapi tantangan untuk 
menuntaskan target Rencana Pembangunan Jangka Menengah Nasional (RPJMN) 20152019 yang menetapkan tarcapainya akses universal $100 \%$ air minum, $0 \%$ pemukiman kumuh dan $100 \%$ stop bebas buang air besar sembarangan (BABS). Berdasarkan data yang dirilis oleh sekretariat Sanitasi Total Berbasis Masyarakat (STBM), hingga 2015 sebanyak 62 juta atau 53\% penduduk perdesaan masih belum memiliki akses terhadap sanitasi yang layak.

Sanitasi merupakan salah satu prasarana dasar perkotaan dan memerlukan perhatian yang khusus dalam pengelolaannya. Penyebab buruknya kondisi sanitasi di Indonesia adalah lemahnya perencanaan pembangunan sanitasi: tidak terpadu, salah sasaran, tidak sesuai kebutuhan, dan tidak berkelanjutan, serta kurangnya perhatian masyarakat pada perilaku hidup bersih dan sehat (PHBS). Kondisi sanitasi yang buruk akan menimbulkan dampak negatif bagi segala aspek kehidupan yang sangat rentan, seperti turunnya kualitas hidup manusia, sumber air menjadi tercemar, munculnya berbagai penyakit seperti diare terutama bagi balita, citra kota/kabupaten menjadi turun, hingga perekenomian kota/kabupaten menurun.

Menurut Darmono ${ }^{[2]}$, tingkat kesehatan sangat dipengaruhi oleh berbagai faktor lingkungan disamping faktor perilaku dan pelayanan kesehatan. Upaya perbaikan kesehatan lingkungan dilakukan untuk mewujudkan mutu lingkungan yang lebih sehat. Hal tersebut antara lain meliputi poin pokok fasilitas sanitasi dasar yaitu sumber air minum, layanan pembuangan sampah, jamban, saluran pembuangan air limbah rumah tangga dan drainase, sedangkan cakupan perilaku hidup sehat yaitu dengan berhenti buang air besar (BAB) sembarangan, cuci tangan pakai sabun, pengelolaan sampah dengan $3 \mathrm{R}$ dan pengelolaan air limbah rumah tangga (drainase lingkungan).

Risiko sanitasi didefinisikan sebagai penurunan kualitas hidup, kesehatan, dan lingkungan yang disebabkan oleh rendahnya akses terhadap layanan dan fasilitas sanitasi serta buruknya perilaku higiene. Kabupaten Sumbawa merupakan salah satu kabupaten yang mengutamakan akses sanitasi sebagai hak dasar masyarakat. Hal ini tertuang dari RPJMD Kabupaten Sumbawa yang menginginkan akses $100 \%$ sanitasi pada masyarakat Sumbawa. Akan tetapi berdasarkan data Profil Kesehatan Kabupaten Sumbawa tahun 2017, akses masyarakat yang memiliki jamban sehat baru sebesar $78.52 \%$ dan desa yang melaksanan Sanitasi Total Berbasis Masyarakat Total hanya sebesar 23\%. Sehingga dengan demikian masih dibutuhkan upaya yang maksimal untuk mencapai angka $100 \%$.

Studi Environmental Health Risk Assessment (EHRA) menganalisis Risiko sanitasi di tingkat rumah tangga dan menerjemahkannya secara kuantitatif dalam bentuk Indeks Risiko Sanitasi (IRS). Hasil analisis EHRA dalam bentuk IRS penting dilakukan mengingat masih rendahnya angka sanitasi total di Kabupaten Sumbawa. Sampai dengan saat ini belum ada hasil penelitian yang menunjukan hasil analisis sanitasi dan kesehatan lingkungan di Kabupaten Sumbawa. Dengan demikian, sebagai baseline dan titik acuan penelitian ini dirasa penting untuk dilakukan. Hal inilah yang menjadi titik tekan yang mendorong peneliti untuk melakukan penelitian tentang Analisis Penilaian Risiko Kesehatan Lingkungan Kecamatan Moyo Utara.

Berdasarkan uraian tersebut, maka rumusan masalah dalam penelitian ini adalah sebagai berikut:

a. Berapa IRS pada aspek sanitasi dasar dan perilaku hidup sehat di Kecamatan Moyo Utara Kabupaten Sumbawa?

b. Bagaimana peta risiko sanitasi Kecamatan Moyo Utara?

c. Apa faktor penyebab tingginya indeks risiko sanitasi pada wilayah Kecamatan Moyo Utara?

Sejalan dengan rumusan masalah yang telah disampaikan, tujuan penelitian ini adalah mengetahui IRS pada aspek sanitasi dasar dan perilaku hidup sehat di Kecamatan Moyo Utara Kabupaten Sumbawa serta membuat peta risiko sanitasi kecamatan.

\section{METODE PENELITIAN}

Penelitian ini menggunakan pendekatan kuantitatif dan kualitatif dengan teknik 
pengumpulan data yaitu wawancara dan pengisisan kuesioner. Penelitian ini dilakukan di Kecamatan Moyo Utara Kabupaten Sumbawa Besar Nusa Tenggara Barat (NTB). Rentang waktu penelitian adalah 6 bulan, sejak bulan April hingga Agustus 2019. Metode yang digunakan adalah random sampling dengan jumlah responden setiap desa minimal 40 rumah tangga yang tersebar di minimal 8 RT terpilih dan responden minimal per RT adalah 5 responden dan dipilih secara random. Proses pengambilan data dilakukan selama 3 bulan yang dilakukan selama Bulan Mei sampai dengan Juli 2019 yang dilanjutkan dengan proses input data dengan menggunakan aplikasi EHRA. Setelah proses input data dengan menggunakan aplikasi, dilanjutkan dengan proses pengolahan dengan menggunakan aplikasi SPSS 16 lalu dilanjutkan dengan proses analisis dengan menggunakan Ms. Office Excel 2010.

\section{Unit sampling utama (Primary} Sampling Unit) adalah wilayah kecamatan Moyo Utara. Unit analisis dalam EHRA adalah rumah tangga, sementara yang menjadi unit respon adalah ibu rumah tangga ${ }^{[3]}$. Ibu dipilih dengan asumsi bahwa mereka relatif lebih memahami kondisi lingkungan berkaitan dengan isu sanitasi serta mereka relatif lebih mudah ditemui dibandingkan bapak-bapak. Ibu dalam EHRA didefinisikan sebagai perempuan berusia 18-60 tahun yang telah atau pernah menikah. Untuk memilih Ibu di setiap rumah, peneliti menggunakan matriks prioritas yang mengurutkan prioritas Ibu di dalam rumah. Prioritas ditentukan oleh status Ibu yang dikaitkan dengan kepala rumah tangga. Bila dalam prioritas tertinggi ada dua atau lebih Ibu, maka usia menjadi penentunya.

Studi EHRA yang dilakukan di Kecamatan Moyo Utara melibatkan 6 desa yang ada di kecamatan tersebut. Jumlah responden secara keseluruhan yang ada dalam penelitian ini adalah 240 orang responden. Setiap desa diwakili oleh 40 orang responden yang berasal dari 8 RT yang berbeda pada masing-masing desa. Unit sampling utama adalah RT (Rukun Tetangga) yang dipilih secara proposional dan random berdasarkan total RT dalam setiap Desa/Kelurahan minimal 40 responden. Ibu rumah tangga (IRT) merupakan responden yang digunakan dalam penelitian ini.Hal ini telah memenuhi proses pengambilan sampel yang disyaratkan oleh stdui EHRA. Keenam desa yang ada dilakukan proses cluster dengan pembagian strata 0 sampai dengan 4. Proses klasterisasi desa ditujukan untuk membagi desa sesuai dengan kategori yang dimaksud.

Tabel 1. Strata Desa di Kecamatan Moyo Utara

\begin{tabular}{llccccc}
\hline & & \multicolumn{5}{c}{ Kriteria Strata } \\
\cline { 3 - 6 } No & \multicolumn{1}{c}{ Desa } & $\begin{array}{c}\text { Kepadatan } \\
\text { Penduduk }\end{array}$ & $\begin{array}{c}\text { Angka } \\
\text { Kemiskinan }\end{array}$ & $\begin{array}{c}\text { Kejadian } \\
\text { Banjir }\end{array}$ & $\begin{array}{c}\text { Melewati } \\
\text { drainase dan } \\
\text { aliran sungai }\end{array}$ & $\begin{array}{c}\text { Golongan } \\
\text { Strata }\end{array}$ \\
\hline 1 & Penyaring & $\sqrt{ }$ & & & & 0 \\
2 & Sebewe & $\sqrt{ }$ & $\sqrt{ }$ & $\sqrt{ }$ & & 1 \\
3 & Baru Tahan & & $\sqrt{ }$ & $\sqrt{ }$ & 2 \\
4 & Kukin & $\sqrt{ }$ & $\sqrt{ }$ & $\sqrt{ }$ & $\sqrt{ }$ & 3 \\
5 & Pungkit & $\sqrt{ }$ & & $\sqrt{ }$ & 4 \\
6 & Songkar & & & &
\end{tabular}

Tahapan persiapan ini dilakukan diawali dengan koordinasi tim peneliti guna menentukan langkah yang akan dilakukan dalam mencapai tujuan penelitian. Setelah itu peneliti melakukan koordinasi dengan wilayah penelitian untuk mendapatkan izin penelitian data awal yang berupa jumlah penduduk, susunan demografi dan kondisi drainase. Adapun tahapan dalam penelitian ini adalah.

1. Tahap persiapan, meliputi pencarian referensi pendukung serta literatur yang berkaitan dengan penelitian. Selain itu pada tahap ini pula akan dipersiapkan instrumen berupa lembar kuesioner dan wawancara serta lembar observasi yang 
akan digunakan untuk mengambil data di lapangan.

2. Tahap pengambilan data, meliputi persiapan kuesioner berupa uji validasi dan penggandaan. Selain itu pada tahap ini merupakan tahap krusial dalam pengambilan data berupa wawancara dan lembar observasi. Setelah proses pengambilan data berlangsung maka akan didapatkan data utuh yang siap untuk dianalisis.

3. Tahap analisis data, data yang didapatkan akan diolah dan dianalisis dengan menggunakan SPSS dan software Epi info. Dihasilkannya data hasil entri dengan Software Epi Info yang siap untuk dianalisis dengan menggunakan SPSS. Sehingga dihasilkannya tabel hasil analisis studi EHRA sampai penentuan IRS.

Klaster risiko sanitasi akan terbagi dalam beberapa kategori yaitu, kurang berisiko, risiko sedang, risiko tinggi dan risiko sangat tinggi.

\section{HASIL DAN PEMBAHASAN}

Hasil penelitian yang didapatkan adalah nilai indeks risiko sanitasi, peta risiko sanitasi dan faktor penyebab buruknya sanitasi di wilayah penelitian. Ketiga masalah penelitian ini merupakan permasalahan utama yang ditemukan di lapangan. Masyarakat masih belum memahami pentingnya aspek sanitasi dan kesehatan lingkungan sehingga cenderung diabaikan al ini pula ang dijumpai di lapangan termasuk pada 5 aspek sanitasi dasar yang diteliti dalam penelitian ini yaitu sumber air, air limbah domestik, genangan air, persampahan dan PHBS.

\section{Gambaran Umum Lokasi Penelitian}

Dalam penerapannya di masyarakat, sanitasi meliputi penyediaan air, pengelolaan limbah, pengelolaan sampah, kontrol vektor, pencegahan dan pengontrolan pencemaran tanah, sanitasi makanan, serta pencemaran udara $^{[4]}$. Studi EHRA menganalisis Risiko sanitasi di tingkat rumah tangga dan menerjemahkan secara kuantitatif dalam bentuk IRS. Hasil analisis EHRA dalam bentuk IRS penting dilakukan karena rendahnya angka sanitasi total di Kabupaten Sumbawa. Belum ada hasil penelitian yang menunjukan hasil analisis sanitasi dan kesehatan lingkungan di Kabupaten Sumbawa. Moyo Utara merupakan salah satu kecamatan di Kabupaten Sumbawa yang memiliki tingkat sanitasi masih rendah. Hal ini terlihat dari data pendahuluan yang dilakukan dan menjadi acuan pemilihan lokasi penelitian. Sebagai baseline penelitian ini dirasa penting untuk dilakukan.

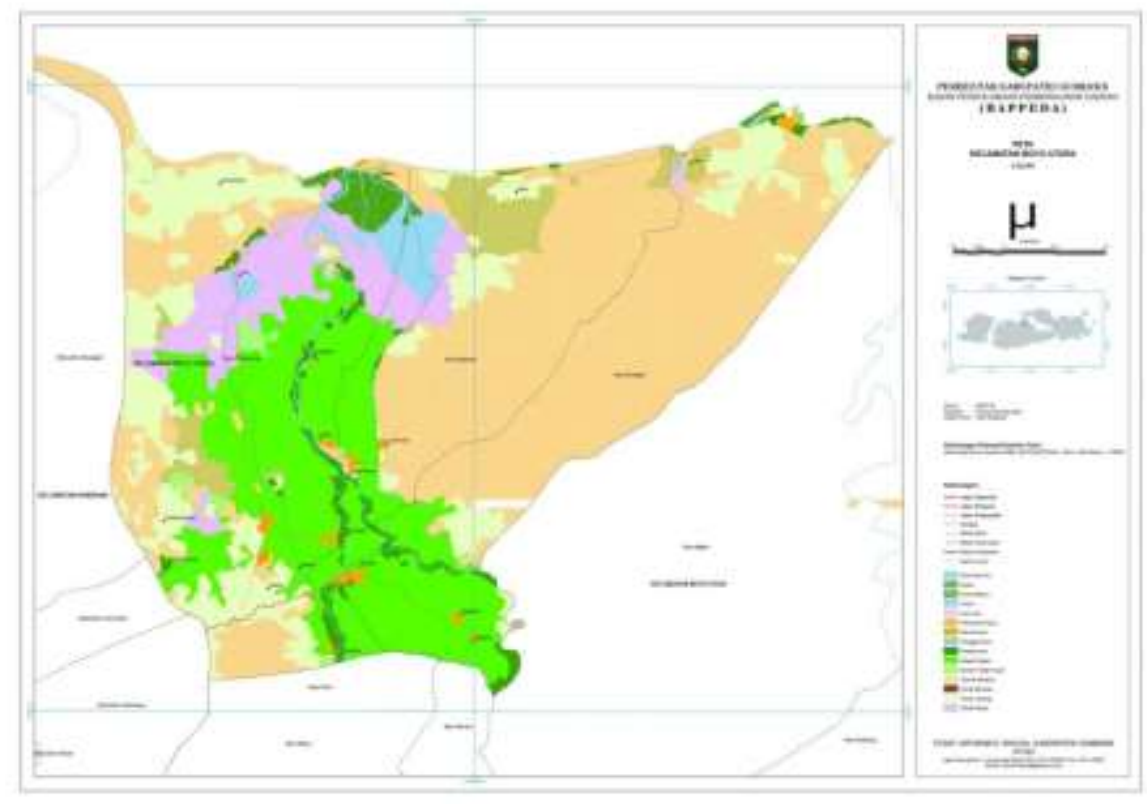

Gambar 2. Peta Kecamatan Moyo Utara

(Sumber : BPS Kab. Sumbawa, 2017) 
Masyarakat Moyo Utara mayoritasnya merupakan petani dan nelayan karena wilayah geografisnya merupakan lahan/ladang kering dan sebagiannya pesisir pantai. Berdasarkan hasil penelitian berikut adalah gambaran umum lingkungan Kecamatan Moyo Utara berdasarkan aspek sanitasi dasar.

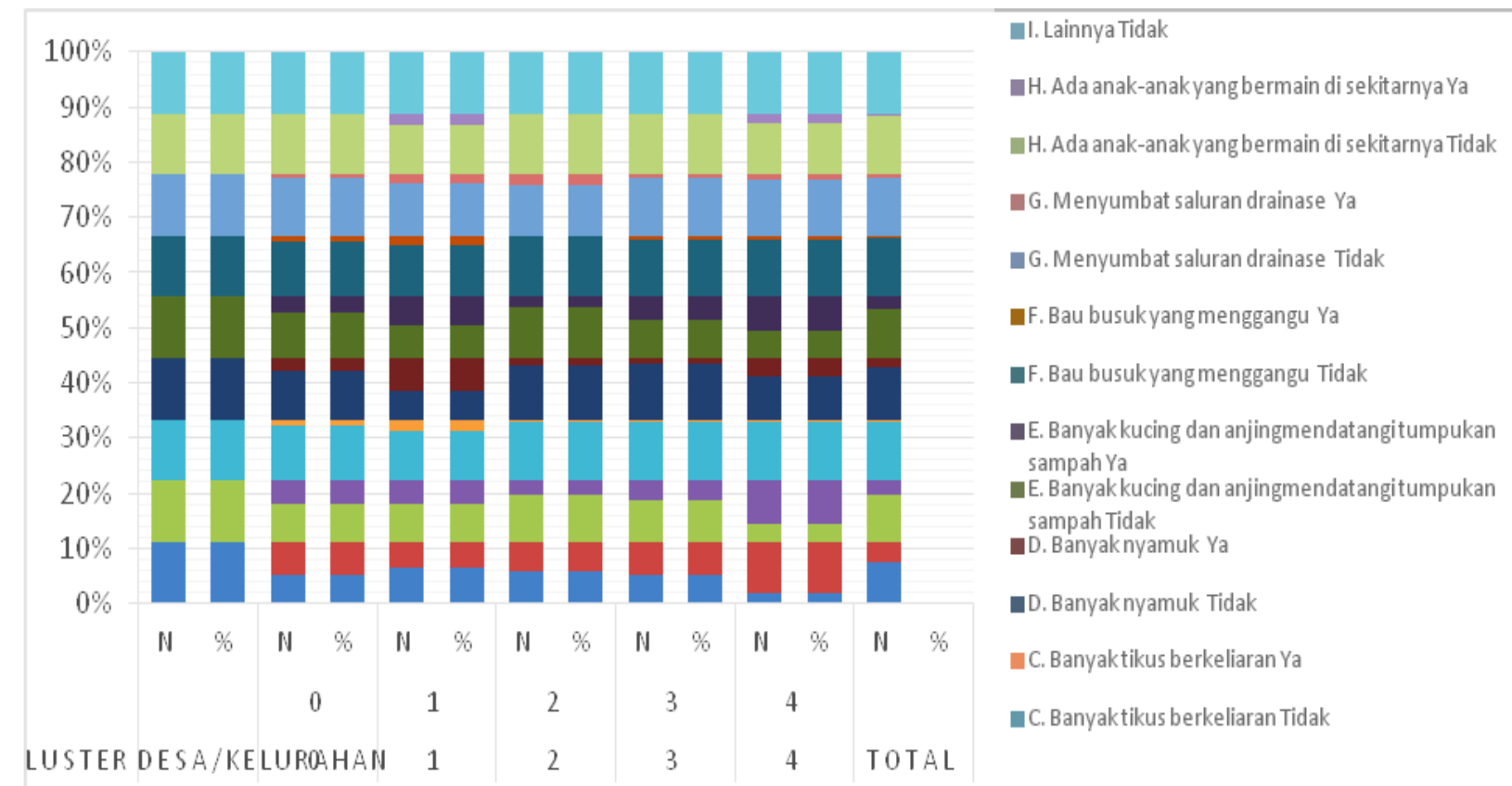

Gambar 3. Kondisi Lingkungan Wilayah Kecamatan Moyo Utara

\section{Gambaran IRS Kecamatan Moyo Utara}

Sanitasi Lingkungan adalah status kesehatan suatu lingkungan yang mencakup perumahan, pembuangan kotoran, penyedian air bersih. Sanitasi lingkungan ditujukan untuk memenuhi persyaratan lingkungan yang sehat dan nyaman ${ }^{[5]}$. Sanitasi merupakan salah satu komponen dari kesehatan lingkungan, yaitu perilaku yang disengaja untuk membudayakan hidup bersih untuk mencegah manusia bersentuh langsung dengan kotoran dan bahan buangan berbahaya lainnya, dengan harapan dapat menjaga dan meningkatkan kesehatan manusia. Kondisi sanitasi di Indonesia memang tertinggal jauh dari Negara-negara tetangga. Dibandingkan dengan Malaysia atau Singapura yang berkomitmen tinggi terhadap kesehatan lingkungan di negaranya, Jakarta hanya menduduki posisi nomor 2 dari bawah setelah Laos dalam pencapaian cakupan sanitasinya. Sanitasi sangat menentukan keberhasilan dari paradigma pembangunan kesehatan lingkungan lima tahun ke depan yang lebih menekankan pada aspek Istilah kesehatan lingkungan seringkali dikaitkan dengan istilah sanitasi/sanitasi lingkungan yang oleh Organisasi Kesehatan Sedunia (WHO), disebutkan pengertian sanitasi lingkungan/kesehatan lingkungan adalah usaha untuk mengawasi beberapa faktor lingkungan fisik yang berpengaruh kepada manusia, terutama terhadap hal-hal yang mempunyai efek merusak perkembangan fisik, kesehatan dan daya tahan hidup.

Sanitasi adalah segala upaya yang dilakukan untuk menjamin terwujudnya kondisi yang memenuhi persyaratan Menkes965/MENKES/SK/ XI/1992 tentang Definisi Sanitasi. Sanitasi adalah kebutuhan dasar manusia dalam rangka kebersihan urusan buang hajat dan limbah serta penyediaan air bersih ${ }^{[6]}$. Menurut POKJA $\mathrm{AMPL}^{[7]}$, IRS dengan menggunakan EHRA mengacu pada lima aspek sanitasi berupa sumber air, air limbah, genangan air, persampahan dan PHBS.

\section{Sumber Air}

Air adalah kebutuhan pokok bagi kehidupan manusia. Permasalahan ketersediaan air bersih bagi masyarakat 
menjadi masalah yang terus dihadapi oleh masyarakat Indonesia akhir-akhir ini. Meningkatnya aktivitas pembangunan dan jumlah penduduk, berakibat pada peningkatan kebutuhan masyarakat akan air bersih. berdasarkan hasil temuan di lapangan, masih ada warga masyarakat yang belum memiliki sumber air sendiri di rumah. Selain itu ada juga warga yang sumber airnya tidak memenuhi syarat air bersih yaitu sumber airnya berasa dan berwarna kekuningan.

2. Saluran pembuangan Air Limbah Saluran Pembuangan Air Limbah (SPAL) adalah perlengkapan pengelolaan air limbah bisa berupa pipa atau pun selainnya yang dipergunakan untuk membantu air buangan dari sumbernya sampai ke tempat pengelolaan atau ke tempat pembuangan. Menurut Direktorat Perumahan ${ }^{[8]}$ pengelolaan air limbah dapat dilakukan dengan membuat saluran air kotor dan bak peresapan dengan memperhatikan ketentuan sebagai berikut:

a. Tidak mencemari sumber air minum yang ada di daerah sekitarnya baik air dipermukaan tanah maupun air di bawah permukaan tanah.

b. Tidak mengotori permukaan tanah.

c. Menghindari tersebarnya cacing tambang pada permukaan tanah.

d. Mencegah berkembang biaknya lalat dan serangga lain.

e. Tidak menimbulkan bau yang mengganggu.

f. Konstruksi agar dibuat secara sederhana dengan bahan yang mudah didapat dan murah.

g. Jarak minimal antara sumber air dengan bak resapan $10 \mathrm{~m}$. Faktanya di lapangan masih ditemukan SPAL yang belum terintegrasi dan pembuangannya dibiarkan tergenang di atas permukaan tanah sehingga memicu bau tidak sedap. Hal ini menjadi salah satu faktor yang menyebabkan tingginya IRS di wilayah Kecamatan Moyo Utara.

\section{Genangan Air Limbah Rumah Tangga}

Genangan air menjadi hal yang penting dalam sanitasi lingkungan karena mampu menjadi vector penyebaran penyakit. Menurut Permenkes nomor 3 tahun 2014 ${ }^{[9]}$ tentang STBM, proses pengamanan limbah cair yang aman pada tingkat rumah tangga untuk menghindari terjadinya genangan air limbah yang berpotensi menimbulkan penyakit berbasis lingkungan. Untuk menyalurkan limbah cair rumah tangga diperlukan sarana berupa sumur resapan dan saluran pembuangan air limbah rumah tangga. Limbah cair rumah tangga yang berupa tinja dan urine disalurkan ke tangki septik yang dilengkapi dengan sumur resapan. Limbah cair rumah tangga yang berupa air bekas yang dihasilkan dari buangan dapur, kamar mandi, dan sarana cuci tangan disalurkan ke saluran pembuangan air limbah. Prinsip Pengamanan Limbah Cair Rumah Tangga adalah.

a. Air limbah kamar mandi dan dapur tidak boleh tercampur dengan air dari jamban.

b. Tidak boleh menjadi tempat perindukan vector.

c. Tidak boleh menimbulkan bau.

d. Tidak boleh ada genangan yang menyebabkan lantai licin dan rawan kecelakaan.

e. Terhubung dengan saluran limbah umum/got atau sumur resapan. Selain genangan yang disebabkan oleh air limbah cair, diperhatikan juga dalam penelitian ini air genangan akibat hujan dan benda-benda yang memicu air tergenang termasuk sampah.

\section{Persampahan}

Pengamanan Sampah Rumah Tangga adalah melakukan kegiatan pengolahan sampah di rumah tangga dengan mengedepankan prinsip mengurangi, memakai ulang, dan mendaur ulang. Pengamanan Sampah Rumah Tangga Tujuan Pengamanan Sampah Rumah Tangga adalah untuk menghindari penyimpanan sampah dalam rumah dengan segera menangani sampah. Pengamanan sampah yang aman adalah pengumpulan, 
pengangkutan, pemrosesan, pendaurulangan atau pembuangan dari material sampah dengan cara yang tidak membahayakan kesehatan masyarakat dan lingkungan. Di Kecamatan Moyo Utara, belum semua wilayah dijangkau oleh truck sampah. Akibatnya masih banyak wilayah yang membuang sampah secara sembarangan. Sehingga meningkatkan IRS yang ada di wilayah tersebut.

\section{Perilaku Hidup Bersih dan Sehat (PHBS)}

PHBS merupakan langkah yang harus dilakukan untuk mencapai derajat kesehatan yang optimal bagi setiap orang. Kondisi sehat tidak serta merta terjadi, tetapi harus senantiasa diupayakan dari yang tidak sehat menjadi hidup yang sehat serta menciptakan lingkungan yang sehat.Upaya ini harus dimulai dari menanamkan pola pikir sehat kepada masyarakat yang harus dimulai dan diusahakan oleh diri sendiri. Upaya ini adalah untuk mewujudkan derajat kesehatan masyarakat setinggi-tingginya sebagai satu investasi bagi pembangunan sumber daya manusia yang produktif. Dalam mengupayakan perilaku ini dibutuhkan komitmen bersama-sama saling mendukung dalam meningkatkan derajat kesehatan masyarakat khususnya keluarga sehingga pembangunan kesehatan dapat tercapai maksimal. Aspek PHBS di wilayah penelitian masih sangat rendah. Aspek PHBS menjadi salah satu aspek yang menyebabkan IRS dii wilayah ini sangat tinggi.

Penilaian risiko kesehatan lingkungan atau yang juga dikenal dengan EHRA adalah studi untuk memahami kondisi fasilitas sanitasi dan perilaku-perilaku yang berisiko pada kesehatan masyarakat. Fasilitas sanitasi yang diteliti mencakup Sumber Air Bersih (SAB), fasilitas jamban yang sehat, tempat sampah rumah tangga, dan SPAL rumah tangga. Perilaku yang diteliti adalah perilaku Cuci Tangan Pakai Sabun (CTPS) dan perilaku pemilahan sampah dan buang air besar sembarangan, pada penelitian ini juga akan dilakukan seberan atau pemetaan risiko kesehatan lingkungan ${ }^{[10]}$.

Berdasarkan hasil penelitian diketahui bahwa wilayah di kecamatan Moyo Utara memiliki indeks risiko sanitasi sebagai berikut.

Tabel 2. Kumulatif Indeks Risiko Sanitasi

\begin{tabular}{lccccc}
\hline \multicolumn{1}{c}{ Variabel } & Strata 0 & Strata 1 & Strata 2 & Strata 3 & Strata 4 \\
\hline Sumber Air & 18 & 20 & 16 & 20 & 18 \\
Air Limbah Domestik. & 66 & 70 & 71 & 65 & 66 \\
Persampahan. & 32 & 92 & 89 & 43 & 43 \\
Genangan Air. & 33 & 27 & 40 & 47 & 53 \\
Perilaku Hidup Bersih Sehat. & 68 & 67 & 64 & 70 & 53 \\
\hline \multicolumn{1}{c}{ Total } & 216 & 277 & 281 & 245 & 233 \\
\hline
\end{tabular}

Sanitasi lingkungan merupakan faktor penting yang harus diperhatikan, terutama sarana air bersih, ketersediaan jamban, pengolahan air limbah, pembuangan sampah, dan pencemaran tanah. Pembuangan tinja dapat langsung mengontaminasi makanan, minuman, sayuran, air tanah, serangga dan bagian tubuh. Perlu pengaturan pembuangan sampah agar tidak membahayakan kesehatan manusia karena dapat menjadi gudang makanan bagi vektor penyakit ${ }^{[11]}$. Tingkat kesehatan dipengaruhi faktor lingkungan selain perilaku dan pelayanan kesehatan.
Upaya perbaikan kesehatan lingkungan dilakukan untuk mewujudkan mutu lingkungan yang lebih sehat. Hal tersebut meliputi poin pokok fasilitas sanitasi dasar yaitu sumber air minum, layanan pembuangan sampah, jamban, saluran pembuangan air limbah rumah tangga dan drainase, sedangkan cakupan perilaku hidup sehat yaitu dengan berhenti BAB sembarangan, cuci tangan pakai sabun, pengelolaan sampah dengan $3 R$ dan pengelolaan air limbah rumah tangga

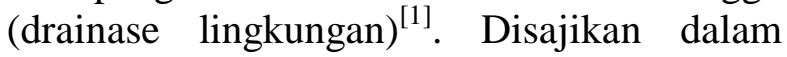
bentuk grafik sebagai berikut. 


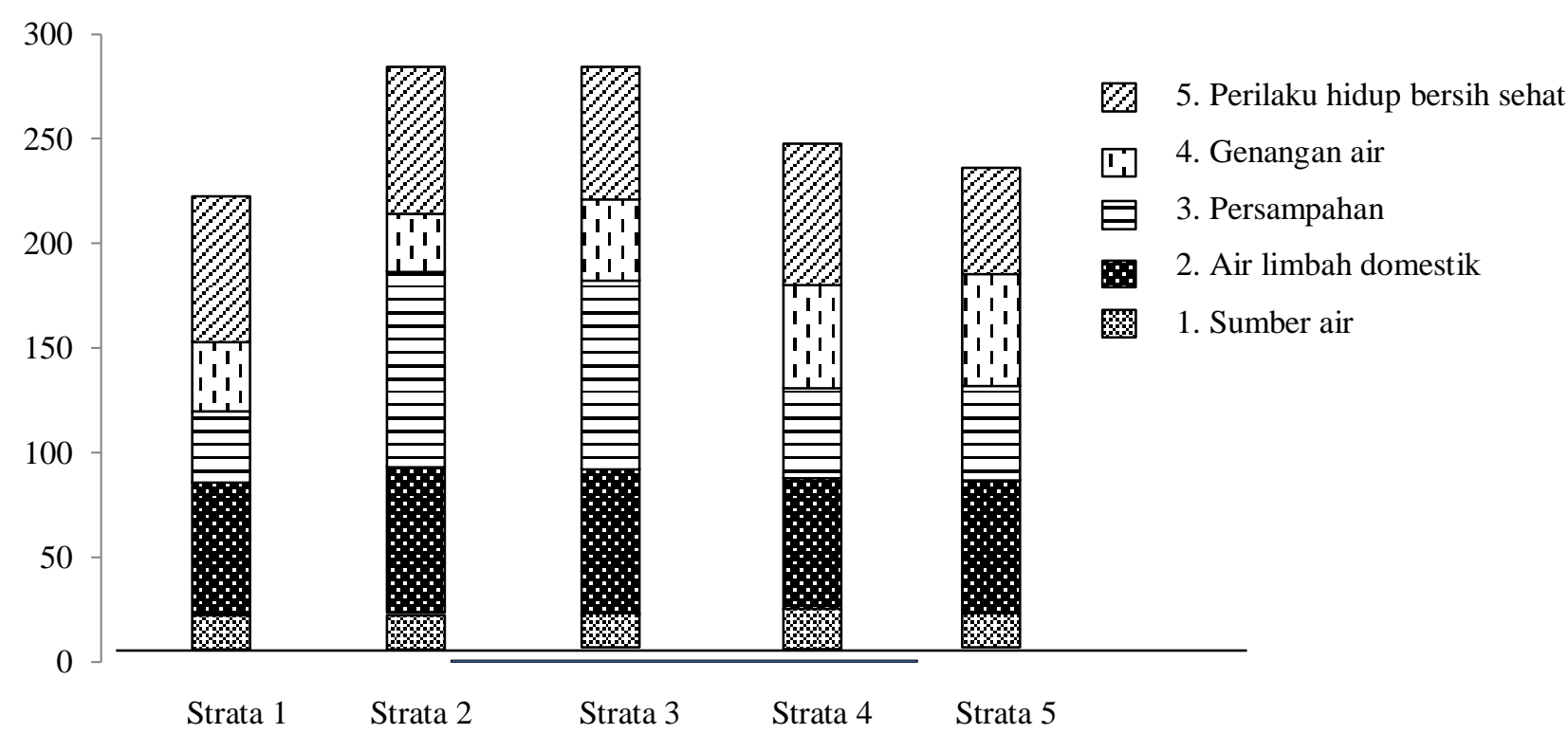

Gambar 4. Grafik Indeks Risiko Sanitasi Kec. Moyo Utara Kab. Sumbawa 2019

Gambar 4 menunjukkan bahwa pada setiap strata wilayah, permasalahan air limbah domestik, persampahan dan PHBS menjadi permasalahan utama yang memiliki tingkat risiko sanitasi yang cukup besar dibandingkan yang lain. Faktor persampahan memang menjadi permasalahan karena tidak semua wilayah mendapatkan akses pengangkutan sampah secara teratur dari pemerintah daerah. Selain itu, pengangkutan sampah di beberapa wilayah di kecamatan ini juga ada yang dikenakan biaya untuk pembiayaan operasional.

Air limbah domestik pada seluruh rumah tangga yang menjadi responden tidak mempunyai sarana pembuangan air limbah yang memadai. Air limbah buangan rumah tangga yang meliputi sisa pemakaian kran, sisa mencuci tangan maupun pakaian, kamar mandi, dapur dan lain-lain dialirkan pada selokan terbuka yang mengalir langsung ke sungai dan bahkan mengalir serta menggenang pada area tanah secara langsung, menurut Yogisutanti $\mathrm{dkk}^{[12]}$, saluran air yang terbuka dapat menjadi penyebab terjadinya penyakit dan mengotori lingkungan sekitarnya.

Perilaku masyarakat dalam membuang air limbah domestik masih kurang baik, karena seharusnya air limbah dibuang pada saluran pembuangan air limbah yang tertutup dan memenuhi persyaratan kesehatan. Faktor PHBS cenderung dikesampingkan karena masyarakat memiliki pola kebiasaan yang telah menjadi hal yang biasa dn wajib dilakukan tanpa memahami apek sanitasi dan kebersihan. Hal ini cenderung menjadi vektor penyakit yang ada di masyarakat.

Tabel 3. Standar Indeks Risiko Sanitasi

\begin{tabular}{lcc}
\hline & $\begin{array}{c}\text { Batas Nilai } \\
\text { Risiko }\end{array}$ & Ket \\
\hline Total Indeks Risiko Max & 266 & \\
Total Indeks Risiko Min & 160 & \\
Interval & 27 & \\
Kategori Area Berisiko & Batas & Batas \\
& bawah & Atas \\
Kurang Berisiko & 160 & 187 \\
Berisiko Sedang & 188 & 214 \\
Risiko Tinggi & 215 & 242 \\
Risiko Sangat Tinggi & 243 & 269 \\
\hline (sumber: Laporan EHRA & Kabupaten & Gresik, \\
2015) & &
\end{tabular}

Kategori risiko memiliki nilai batas masing-masing dengan batas atas dan batas bawah. Selain itu, kategori area beresiko ditunjukkan dengan warna berbeda. Hal ini ditujukan untuk mempermudah pengggambaran pada peta sanitasi suatu wilayah. 
Tabel 4. Klasifikasi Kategori Risiko Desa

\begin{tabular}{lccc}
\hline \multicolumn{1}{c}{ Desa } & $\begin{array}{c}\text { Nilai } \\
\text { risiko }\end{array}$ & $\begin{array}{c}\text { Kategori } \\
\text { Risiko }\end{array}$ & $\begin{array}{c}\text { Indeks } \\
\text { Risiko }\end{array}$ \\
\hline Penyaring & 216 & Tinggi & 3 \\
Sebewe & 277 & Sangat Tinggi & 4 \\
Baru Tahan & 281 & Sangat Tinggi & 4 \\
Kukin & 245 & Sangat Tinggi & 4 \\
Pungkit & 233 & Sangat Tinggi & 4 \\
Songkar & & & \\
\hline
\end{tabular}

Berdasarkan hasil penelitian, wilayah desa yang dijadikan lokasi penelitian memiliki kategori risiko tinggi dan sangat tinggi terkait dengan Risiko Sanitasinya. Dari Enam desa hanya 2 desa yang berada pada kategori risiko tinggi sedangkan 4 desa lainnya masuk dalam kategori sangat tinggi. Jika digambarkan dalam bentuk peta maka akan terlihat sebagai berikut.

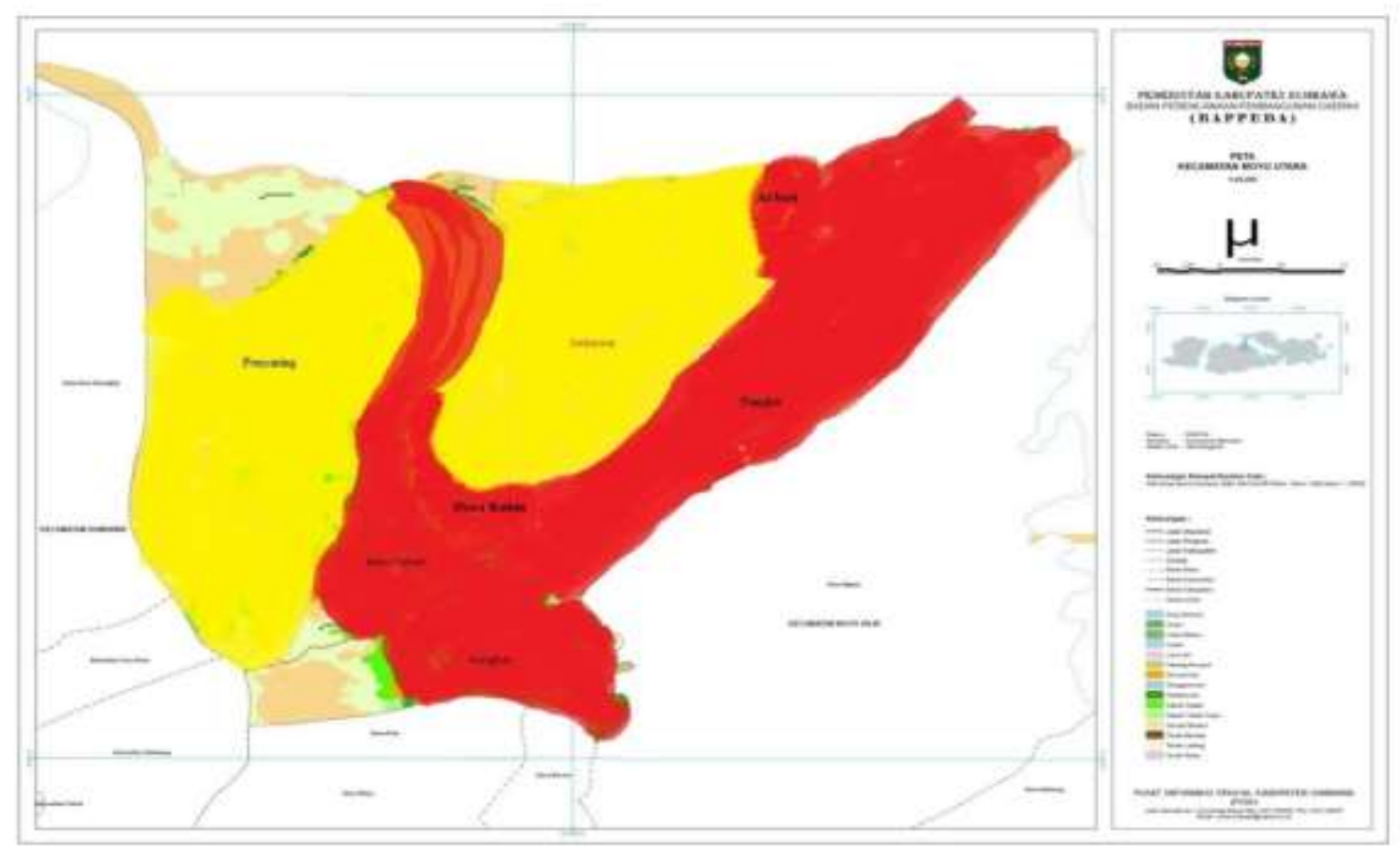

Gambar 5. Peta Risiko Sanitasi wilayah Kecamatan Moyo Utara

Warna merah pada peta menunjukkan wilayah tersebut termasuk dalam wilayah dengan indeks risiko sanitasi sangat tinggi sedangkan Warna kuning pada peta menunjukkan wilayah tersebut termasuk dalam wilayah dengan indek risiko sanitasi tinggi. Berdasarkan hasil wawancara dengan key informan dan pengamatan langsung di lapangan, ditemukan bahwa beberapa faktor yang menjadi penyebab risiko sanitasi yang sangat tinggi di Kecamatan Moyo Utara adalah penduduk yang cenderung mengabaikan pentingnya perilaku hidup sehat, kurangnya tingkat pemahaman dan pendidikan, kurangnya akses pengangkutan sampah, aliran SPAL yang tidak diperhatikan sehingga air buangan limbah yang dibuang begitu saja dan kepemilikan jamban sehat yang masih jauh dari kata cukup, serta masih tingginya tingkat kebiasaan BABS. Hal ini juga sejalan dengan hasil penelitian yang dilakukan oleh Susilawaty dkk, pada tahun 2018 bahwa beberapa faktor yang menjadi penyebab risiko sangat tinggi di RW 1 adalah penduduk yang menyimpang dari perilaku hidup sehat, tingkat pendidikan, kurangnya kepemilikan tempat sampah, kepemilikan SPAL dan kepemilikan jamban, serta tingginya tingkat kebiasaan Buang Air Besar Sembarangan.

Dalam hal ini, diperlukan risk communication agar masyarakat mengetahui dan memahami besaran risiko sanitasi lingkungan tempat tinggalnya, sehingga ada upaya pencegahan dalam bentuk peningkatan cakupan rumah tangga dan individu berperilaku bersih dan sehat. Menurut Tambuwun $\mathrm{dkk}^{[13]}$ faktor sanitasi lingkungan yang buruk menimbulkan penyakit diare pada anak dan balita. Hal ini terbukti dari hasil 
penelitian yang menyatakan ada hubungan antara kondisi sanitasi dengan kejadian diare. Sehingga dengan tinngginya angka IRS pada Wilayah Kecamatan Moyo Utara ini dikhawatirkan akan menimbulkan penyakit diare ataupun penyakit akibat buruknya sanitasi lainnya.

\section{KESIMPULAN}

1. Indeks risiko sanitasi di wilayah Kecamatan Moyo Utara masuk dalam kategori risiko tinggi dan sangat tinggi

2. Faktor yang menjadi penyebab risiko sanitasi yang sangat tinggi di Kecamatan Moyo Utara adalah penduduk yang cenderung mengabaikan pentingnya perilaku hidup sehat, kurangnya tingkat pemahaman dan pendidikan, kurangnya akses pengangkutan sampah, aliran SPAL yang tidak diperhatikan sehingga air buangan limbah yang dibuang begitu saja dan kepemilikan jamban sehat yang masih jauh dari kata cukup, serta masih tingginya tingkat kebiasaan BABS.

\section{REKOMENDASI}

Penelitian ini dapat menjadi acuan pemerintah kecamatan dan kabupaten sebagai upaya penanggulangan serta perbaikan sanitasi masyarakat.

\section{UCAPAN TERIMA KASIH}

Terima kasih kepada Kementerian Riset dan Teknologi dan Pendidikan Tinggi yang telah membiayai penelitian ini dalam skema Penelitian Dosen Pemula (PDP).

\section{REFERENSI}

[1] Kementerian Kesehatan RI, 2016, Sanitasi Total Berbasis Masyarakat (STBM), Jakarta, Kementerian Kesehatan RI.

[2] Darmono, 2010, Lingkungan Hidup dan Pencemaran, Jakarta, UI Press.

[3] POKJA AMPL, 2015, Panduan Praktis Pelaksanaan EHRA (Environmental Health Risk Assessment/Penilaian Risiko Kesehatan karena Lingkungan),
Jakarta, Kementerian Lingkungan Hidup Republik Indonesia.

[4] Chandra, 2007, Pengantar Kesehatan Lingkungan, Jakarta, Penerbit Buku Kedokteran EGC.

[5] Sidhi, Nugrahani, A., Raharjo, M., Astorina, N., Dewanti, Y., 2016, Hubungan Kualitas Sanitasi Lingkungan Dan Bakteriologis Air Bersih Terhadap Kejadian Diare Pada Balita Di Wilayah Kerja Puskesmas Adiwerna Kabupaten Tegal, Jurnal Kesehatan Masyarakat, 4 (3).

[6] Azhar, Jumadil, Susilawati, A., Saleh, M., 2016, Penilaian Risiko Kesehatan Lingkungan di Dusun Kokoa Desa Marannu Kecamatan Lau Kabupaten Maros Tahun 2015, Jurnal Higiene, 2 (2).

[7] POKJA AMPL, 2015, Indeks Risiko Sanitasi (IRS), Jakarta, Kementerian Lingkungan Hidup Republik Indonesia.

[8] Direktorat Perumahan, 1990, Ditjen Cipta Karya-Departemen Pekerjaan Umum, Pembuatan Saluran Bekas Mandi dan Cuci, Jakarta, Departemen Pekerjaan Umum.

[9] Peraturan Kementerian Kesehatan RI Nomor 3, 2014, Sanitasi Total Berbasis Masyarakat (STBM), Jakarta, Kementerian Kesehatan RI.

[10] Indonesia Urban Water, Sanitation, and Hygiene (IUWASH), 2011, Sanitasi dan Kebersihan Perkotaan Indonesia, Sulawesi Selatan.

[11] Kasnodihardjo, Elsi, E., 2013, Deskripsi Sanitasi Lingkungan, Perilaku Ibu, dan Kesehatan Anak, Jurnal Kesehatan Masyarakat Nasional, 7 (9).

[12] Yogisutanti, G., Hotmaida, L., Fuadah, F., Ardayani, T., 2018, Upaya Peningkatan Pengetahuan Tentang Pentingnya Saluran Pembuangan Air Limbah Rumah Tangga di Kelurahan Ciseureuh Kecamatan Regol Kota Bandung, JURNAL ABDIMAS UBJ Jurnal Pengabdian kepada Masyarakat, 116-124. 
[13] Tambuwun, F., Ismanto, A. Y., dan Silolonga, W., 2015, Hubungan Sanitasi Lingkungan dengan Kejadian Diare Pada Anak Usia Sekolah di Wilayah Kerja Puskesmas Bahu Manado, eJournal keperawatan (e-Kp), 3 (2). 